\title{
Marine Microbial Bioactive Compounds: New Way to Treat Resistance of Neglected Tropical Diseases
}

\author{
Duong Nguyen Thi Thuy* and Thao Mai Phuong \\ VN-UK Institute for Research and Executive Education, The University of Danang, Vietnam
}

Submission: November 04, 2019; Published: December 03, 2019

Corresponding author: Duong Nguyen Thi Thuy, VN-UK Institute for Research and Executive Education, The University of Danang, Vietnam

\section{Mini Review}

The neglected tropical diseases (NTDs) are most prevalent in cause severe and lifelong impairment in the world. Causing of these infectious diseases belongs to several pathogenesis groups, including vector-borne protozoa, bacteria and two species of nontuberculosis mycobacteria. Despite causing serious complications, NTDs has been rarely concerned because the majority of cases occur in underdeveloped countries, whose health care standards are only acceptable to poor [1]. Nevertheless, recent studies have highlighted major technology hubs even markedly increased susceptibility to NTDs because natural population growth and over longstanding rural-urban migration. So far, NTDs matter in large modern cities in Japan, China, Singapore, Taiwan, which have been stayed in vague state and weakly control in diagnosis and treatment [2]. In addition, it has been indicated that these diseases can also drive patients get both serious physical and psychosocial damage during their long lived-life [3].

Efforts in isolation and preventing infectious diseases are more difficult than ever before under an international spread of multidrug resistance in bacteria. Notably, Salmonella species as a pathogenesis organism of various infections in patients that is a significant cause of morbidity and mortality worldwide. Not only does the burden on the food industry, but it also leads to several co-morbidities, such as HIV infection, malaria, and malnutrition $[1,4]$. It has been estimated that there are approximately $20-25 \%$ of case fatality in blood stream infection in African adults and children. Non-typhoidal Salmonella disease include respiratory symptoms, fever, and hepatosplenomegaly. Moreover, S. Typhimurium ST313 which has emerged in sub-Saharan Africa is predominantly becoming a multidrug resistance factor in the health services around the world [5].

Basically, antimicrobial chemotherapy commonly used in the treatment patient with bacterial infections. Extendedspectrum antimicrobials like chloramphenicol, trimethoprimsulfamethoxazole were recently shown to have efficacy generally for many infected Salmonella sp. cases. Unfortunately, microbes can withstand killing by bactericidal antibiotics through phenotypic changes mediated by their natural inherited genome. These genes have ability to resist inhibitory effects of antibiotics, thereby degrading drug activation to the site of infection. Studies have shown that the disabled phenomenon of bacteria to antibiotic might be resistance, tolerance or persistence [6]. Plus, the unreasonable antibiotic treatment could induce drugresistant mutation in microbiome. Biofilm is an important virulence determinant of causative pathogenicity of Salmonella species. This glue-like substance is involved in protection bacteria from harm of therapeutic compounds [7]. Obviously, there are urgently needed in finding new strategy to approach and then, finding new effective drug for patient who get NTDs, especially bacteria-related disorders.

To access new sources of anti-infective drugs, natural products (NPs), it has been proven that the marine environment is a rich origin with considerable antimicrobial compounds like anti-fungal, anti-parasitic, anti-bacterial, anti-virus medicines. According to the stream of using NPs, the discoveries of marine's metabolite products have remarkably increased in quantity and quality [8]. A recent design of marine fungi Penicillium spderived compounds show its possession through invaluable actions against microbe's ability to persist, multiply, and produce virulence [9]. Marine microorganisms are an invaluable source of novel active secondary metabolites possessing various biological activities [10]. Butanolides are a class of lactones with a four-carbon heterocyclic ring structure is now show the ability of anti-macrofouling compound, which has been found marine Streptomyces sp. resin. They are not only effective prevent the biofilm formation, but also eliminated pre-formed biofilms of testing model [11]. The purification with thin-layer chromatography of Phomopsis sp. XP-8 broth showed significant inhibition on multi-drug resistance of foodborne pathogens [12]. The data showed marine metabolites contain useful bioactive compounds that can be used to prevent bacterial actions [13]. Hence, marine metabolites need to be evaluated, considered and 
researched more as one of the most essential sources regarding potential products in research, which can bring their power from bench to bedside.

\section{References}

1. N Feasey, M Wansbrough Jones, DCW Mabey, A W Solomon (2010) Neglected tropical diseases. Br Med Bull 93(1): 179-200.

2. P J Hotez (2019) The rise or fall of Neglected Tropical Diseases in East Asia Pacific. Acta Tropica 105182.

3. F Bailey, J Eaton, M Jidda, W H van Brakel, D G Addiss, et al. (2019) Neglected Tropical Diseases and Mental Health: Progress, Partnerships, and Integration. Trends Parasitology 35(1): 23-31.

4. MJ Albert, Bulach D, Alfouzan W, Izumiya H, Carter G, et al. (2019) Nontyphoidal Salmonella blood stream infection in Kuwait: Clinical and microbiological characteristics. PLoS Negl Trop Dis 13(4): e0007293.

5. N A Feasey, G Dougan, R A Kingsley, R S Heyderman, and MA Gordon (2012) Invasive non-typhoidal salmonella disease: An emerging and neglected tropical disease in Africa. Lancet 379(9835): 2489-2499.

6. M H Pontes and EA Groisman (2019) Slow growth determines nonheritable antibiotic resistance in Salmonella enterica. Science Signaling 12(592): eaax3938.

7. MM Soltan Dallal, M Khalifeh Gholi, H Rahmani, S Sharifi yazdi, S Haghighat Khajavi, et al. (2019) Study of biofilm formation in Salmonella species isolated from food. The European Research Journal.
8. G Brahmachari (2019) Therapeutics from natural products against neglected tropical diseases: an overview. Discovery and Development of Therapeutics from Natural Products Against Neglected Tropical Diseases.

9. U R Abdelmohsen, Balasubramanian S, Oelschlaeger TA, Grkovic T, Pham NB, et al. (2017) Potential of marine natural products against drug-resistant fungal, viral, and parasitic infections. The Lancet Infectious Diseases, 17(2): e30-e41.

10. H Minh, T Le, Q T Do, M Huong, T Doan, et al. (2017) Metabolites from the Marine Fungi Penicillium sp 111.

11. Q Yin, Liang J, Zhang W, Zhang L, Hu ZL, et al. (2019) Butenolide, a Marine-Derived Broad-Spectrum Antibiofilm Agent Against Both Gram-Positive and Gram-Negative Pathogenic Bacteria. Mar Biotechnol 21(1): 88-98.

12.X Zhao, Y Zhang, J Shi, Y Liu, Y Lu, et al. (2019) Biosynthesis of antibacterial compound against multidrug resistant foodborne pathogens by Phomopsis sp. XP-8. Food Control 95: 223-231.

13. H Hamayeli, M Hassanshahian, M Askari Hesni (2019) The antibacterial and antibiofilm activity of sea anemone (Stichodactyla haddoni) against antibiotic-resistant bacteria and characterization of bioactive metabolites. International Aquatic Research 11(1): 85-97.

\section{Your next submission with Juniper Publishers} will reach you the below assets

- Quality Editorial service

- Swift Peer Review

- Reprints availability

- E-prints Service

- Manuscript Podcast for convenient understanding

- Global attainment for your research

- Manuscript accessibility in different formats ( Pdf, E-pub, Full Text, Audio)

- Unceasing customer service

Track the below URL for one-step submission https://juniperpublishers.com/online-submission.php 